\title{
Elements of Strategic Planning and Management in Municipal Government: Status after Two Decades
}

\begin{abstract}
This article focuses on the use of strategic planning and management processes in municipal governments with populations over 25,000. Strategic planning has been used in municipalities for 20 years now, but little is known about how it is used and the results obtained. In particular, we explore whether municipal governments tie other components of the overall strategic management process to their strategic plans. Findings do not show a dramatic expansion in the use of strategic planning, but there is some evidence of growing sophistication, as demonstrated by links to other management and decision-making activities. Managers were enthusiastic about their experiences with strategic planning and largely satisfied with their achievement of goals and objectives. Overall, we find a raising of the bar as far as strategic planning is concerned, but the use of comprehensive strategic management is only beginning to develop in a small number of leading-edge municipalities.
\end{abstract}

Strategic planning was introduced into the public sector 20 years ago, with much of the early literature focusing on local government applications (Dodge and Eadie 1982; Eadie 1983; Sorkin, Ferris, and Hudak 1984; Denhardt 1985). Over the past two decades, academics and practicing professionals have shown a sustained interest in strategic planning, and it has become a centerpiece of orthodox public management. Indeed, a recent study of the public management literature from a practitioner's perspective found strategic planning to be the most frequently discussed topic in at least one major public administration journal (Streib, Slotkin, and Rivera 2001). Beyond strategic planning itself, over the past several years interest has also focused on the broader process of strategic management in the public sector (Vinzant and Vinzant 1996a; Poister and Streib 1999; Zanetti and Cunningham 2000).

The Government Performance and Results Act of 1993 requires federal agencies to develop strategic plans and tie them to budgets and performance measures, and many states have imposed similar results-oriented requirements through legislation or executive mandates (Broom 1995; Melkers and Willoughby 1998; Aristigueta 1999). Thus, 60 percent of a sample of state agencies responding to a 1995 survey reported using some form of strategic planning (Berry and Wechsler 1995). In contrast, there is no blanket requirement for local government jurisdictions to use particular approaches to planning and management. However, a decade ago, another study found that nearly 40 percent of municipal jurisdictions with populations over 25,000 had engaged in strategic planning on a citywide basis (Poister and Streib 1994). On the other hand, a number of authors have detailed the difficulty of using strategic planning effectively in local government settings (Swanstrom 1987; Gargan 1989; Streib 1992; Backoff, Wechsler, and Crew 1993)

\section{Strategic Planning and Management}

The purpose of strategic planning is, as Eadie (2000) suggests, to maintain a favorable balance between an or-

Theodore H. Poister is a professor of public administration in the Andrew Young School of Policy Studies at Georgia State University, where he specializes in strategic planning and management, performance measurement, and quality improvement processes in government agencies, particularly at the state and local levels. Poister's new book, Measuring Performance in Government and Nonprofit Organizations, was recently released by Jossey-Bass. E-mail: tpoister@gsu.edu.

Gregory Streib is a professor of public administration in the Andrew Young School of Policy Studies at Georgia State University, where he specializes in local government management and applied research methods. His research addresses strategic planning, pay for performance, health care cost reduction, performance measurement, reinventing government, and the implementation of e-governance initiatives. E-mail: gstreib@gsu.edu. 
ganization and its environment over the long run. Strategic planning has been defined as "a disciplined effort to produce fundamental decisions and actions that shape and guide what an organization is, what it does, and why it does it" (Bryson 1995). It provides a systematic process for gathering information about the big picture and using it to establish a long-term direction and then translate that direction into specific goals, objectives, and actions. It blends futuristic thinking, objective analysis, and subjective evaluation of goals and priorities to chart a future course of action that will ensure the organization's vitality and effectiveness in the long run. "At best ... it permeates the culture of an organization, creating an almost intuitive sense of where it is going and what is important" (Osborne and Gaebler 1992, 234).

Over the years a conventional strategic planning process has evolved, based on approaches developed by Bryson (1995), Nutt and Backoff (1992), and others (Koteen 1989), which typically involves clarifying mission and values, developing a vision of the future, analyzing external challenges and opportunities, assessing internal strengths and weaknesses, developing strategic goals and objectives, identifying strategic issues, developing and evaluating alternative strategies, and developing action plans. Yet, a lively debate continues regarding how to go about strategic planning in government in terms of scope (Kaplan and Norton, 1996; Ellingson and Wambsganss 2001), content (Hatry 2002), involvement and participation (Gabris 1989; Geletkanycz and Hambrick 1997; Franklin 2001; Markoczy 2001), and approach (Toft 1989; Roberts 2000).

The more important issue, however, concerns putting plans into action. Strategic planning is an action-oriented type of planning that is useful only if it is carefully linked to implementation-and this is often where the process breaks down. Strategic plans do not implement themselves, and they may well be resisted by employees who feel threatened by change or by the institution of additional controls (Franklin 2000) or feel stymied by labor-management conflicts (Donald, Lyons, and Tribbey 2001). Moreover, public managers may fail to link their strategic planning efforts to other critical decision-making processes. Mintzberg (1994) is one of the most vocal critics of strategic planning precisely because organizations' planning activities are too often completely divorced from performance measurement and resource allocation.

Thus, effective strategic management, the all-encompassing process of developing and managing a strategic agenda, is of the utmost importance. Koteen defines strategic management as a broad concept that "embraces the entire set of managerial decisions and actions that determine the long-run performance of an organization" (1989, 18), while Toft portrays it as "an advanced and coherent form of strategic thinking, attempting to extend strategic vision throughout all units of the organization, encompassing every administrative system" $(1989,6)$. Vinzant and Vinzant characterize strategic planning as the "cornerstone" of strategic management, but they also say that "successful implementation of strategic management requires an assessment of organization capacities in such areas as managerial capability, power structure, culture, leadership, and organizational structure" (1996b, 203). Others agree: "Strategic planning is the primary element but not the essence of strategic management. The other components ... include implementation and evaluation" (Halachmi, Hardy, and Rhoades 1993, 165).

Consistent with this view, Nutt and Backoff (1992), Bryson (1995), and others have discussed the importance of implementing strategic plans by anchoring lower-level planning processes in the strategic plans themselves. Thus, some organizations attempt to ensure their strategic plans drive decisions at all levels by requiring major divisions and subunits to develop their own strategic plans, annual plans, business plans, or action plans that support enterprise-level strategic goals and objectives (Hendrick 2000; Poister and Van Slyke 2002).

As Steiss defined it well nearly two decades ago, "Strategic management is concerned with deciding in advance what an organization will do in the future (planning), determining who will do it and how it will be done (resource management), and monitoring and enhancing ongoing activities and operations (control and evaluation)" $(1985,9)$. In a seminal piece published a decade later, Vinzant and Vinzant (1996a) identified performance measures derived directly from strategic goals and objectives, and links between strategic plans and budgets, as critical elements of the strategic management process. More recently, Poister and Streib (1999) added performance management-providing direction and control over the work of managers and employees to ensure their efforts focused on achieving strategic goals and objectives- to the list.

\section{Purpose}

Newcomer et al. point out the need for multifaceted research on performance-based management in the public sector, particularly studies that use quantitative analysis to "assess impacts of performance measurement or systematically analyze factors affecting performance oriented government" $(2002,192)$. While strategic planning is a central element, strategic management is a more holisticand much more demanding-process. More importantly, the results that a government jurisdiction or agency can achieve through strategic planning depend on the effectiveness of its overall capacity for strategic management. Many public managers have embraced strategic planning, but it is unlikely to produce the benefits they anticipate 
unless they drive it through their budgeting, measurement, and performance management processes. Thus, this research investigates the current state of the practice of strategic planning and management in U.S. municipal government, focusing specifically on the perceived impact of these tools and the particular elements that are most directly related to success in using them. The specific objectives of this research are as follows:

- Survey the extent to which formal, citywide strategic planning is used among municipal governments with populations over 25,000

- Explore the use of various planning and management elements in cities that have undertaken strategic planning efforts

- Examine the extent to which these cities tie other components of the overall strategic management process to their strategic plans

- Gauge municipal managers' satisfaction with the implementation and achievement of strategic goals and objectives, as well as their assessment of the impact of their strategic planning efforts

- Identify elements of strategic planning and management that appear to be most closely related to overall positive results.

\section{Survey Methodology}

To address these issues, we conducted a survey of municipal officials in all jurisdictions with populations of 25,000 or more. Following some introductory questions regarding the type of budgeting systems, performance management systems, and measurement systems used by these governments, the instrument asked a few questions about the status of strategic planning in these jurisdictions and, for those that had engaged in strategic planning, a number of questions regarding specific steps in the process. The core of the survey, then, consisted of sets of Likert items concerning the overall strategic management process, focusing on the involvement of stakeholders in strategic planning, the relationship of strategic planning to budgeting and management, and the link between strategic plans and performance measures. The instrument concluded with questions about the impact of strategic planning and officials' satisfaction with the overall results.

We mailed the survey to 1,247 senior officials in municipal governments - primarily city managers, chief administrative officers, and finance directors - using names and addresses provided by the International City/County Management Association. With one mailing and one follow-up postcard reminder, we received a total of 512 completed surveys for an overall response rate of 41 percent, which is considered good for this type of survey. The resulting sample is highly representative of all U.S. cities over 25,000 in terms of population, region, metropolitan status, and form of government, with the exception of some minor underinclusion of the largest cities, eastern cities, and mayor-council cities.

\section{Use of Strategic Planning}

Of the 512 municipal managers who responded to this survey, 225 (44 percent) reported their jurisdictions had initiated formal, citywide strategic planning over the past five years, while the remaining 56 percent indicated they had not done so. The 44 percent reporting some use of strategic planning on a citywide basis is somewhat higher than the approximately 38 percent found by Poister and Streib (1994) nearly 10 years ago, suggesting a modest spread in the use of this approach over the past decade. However, there is reason to believe that earlier studies may have exaggerated the use of strategic planning, as they included just a question or two on the topic. The current survey is less likely to be subject to such distortion because the instrument was extensive, cumulative, and focused only on strategic planning. Thus, the reported 44 percent may represent a greater increase in the use of strategic planning in U.S. cities than just 6 percentage points.

The current survey asked respondents who reported involvement with strategic planning about the status of those efforts. Twenty-four percent indicated their jurisdictions had initiated strategic planning efforts, though their first plan had not been completed (figure 1). On the other hand, almost another quarter of the respondents reported they had completed one strategic planning effort, while slightly

\section{Figure 1 Municipalities Reporting Successive Levels of Strategic Management}

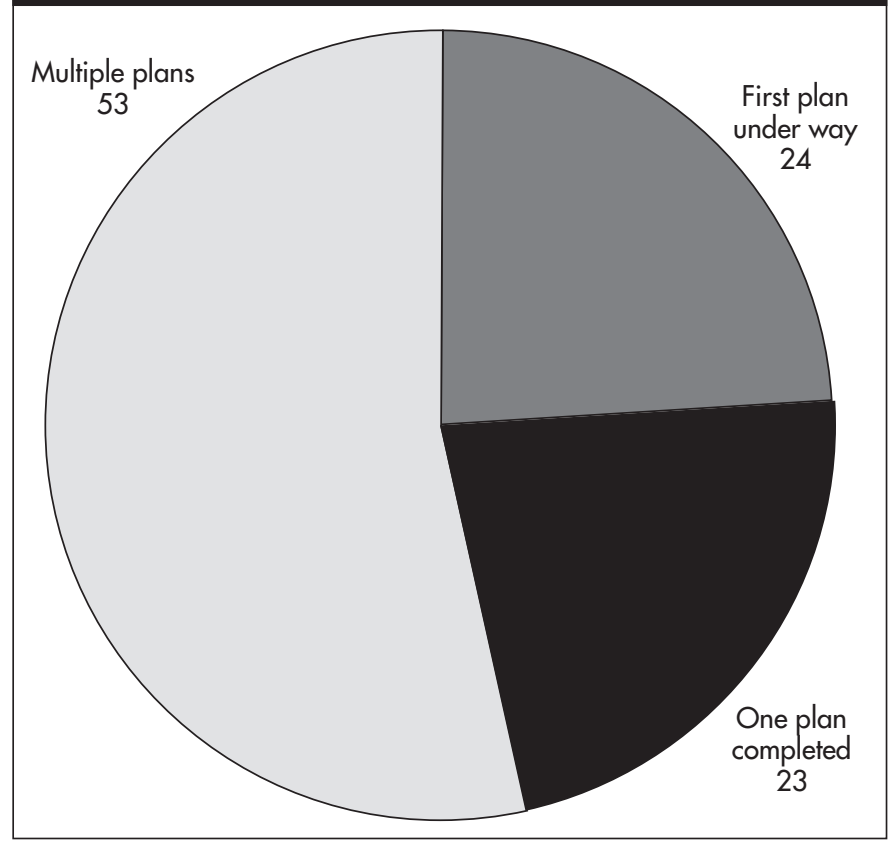


more than half indicated their municipal governments had completed two or more strategic plans at that point.

\section{Stakeholder Involvement}

Respondents from local governments with formal strategic planning efforts were asked whether stakeholders were involved in these processes. These efforts almost always included city managers or chief administrative officers, along with department heads and other senior managers (table 1). Looking at elected officials, roughly 80 percent of the jurisdictions reported the city council and the mayor were centrally involved in these efforts. Not surprisingly, fewer than half of the respondents indicated that lowerlevel employees were involved in strategic planning, while slightly more than 60 percent reported that citizens and other external stakeholders had been brought into their strategic planning efforts.

\section{Table 1 Municipalities Involving Various Stakeholders in Strategic Planning}

The mayor has been centrally involved in the development of our strategic plan.

The city council has been centrally involved in the development of our strategic plan.

The city manager or chief administrative officer has been centrally involved in the development of our strategic plan.

Department heads and other senior managers have been centrally involved in the development of our strategic plan. 93 percent Citizens and other external stakeholders have been centrally involved in the development of our strategic plan.

Lower-level employees have been centrally involved in the development of our strategic plan.

62 percent

46 percent

Note: Percentages are based on the 225 respondents reporting that their jurisdictions had undertaken formal strategic planning efforts in the past five years.

\section{Strategic Planning Elements}

Figure 2 shows the proportion of respondents from jurisdictions with strategic planning efforts who reported the use of particular elements. The most frequently reported elements were the development of goals and objectives (cited by 92 percent of respondents) and the development of a vision for the future ( 89 percent), followed by review of their organizational mission and the development of action plans (both cited by 78 percent). Thus, these municipal strategic planning processes emerge as being mission driven and focusing on the future, setting goals, and initiating plans for implementation.

Elements reported by somewhat fewer respondents included the identification of stakeholders' needs and concerns (72 percent) and the development of strategic agendas (71 percent), followed by the evaluation of internal strengths and weaknesses (60 percent) and the assessment of external threats and opportunities (57 percent). Elements reported by the fewest respondents were clarification of organizational mandates (53 percent) and, importantly, feasibility assessment of proposed strategies (36 percent). Thus, it appears that fewer of these municipalities focus directly on external mandates and assuring the successful implementation of their strategic plans.

\section{Strategic Management Practices}

Looking at implementation, a principal purpose of this survey is to gauge the extent to which municipalities that engage in strategic planning tie their plans to other management processes to assure the accomplishment of strategic goals and objectives. One model for assessing the successful design and implementation of a strategic man-

\section{Figure 2 Reported Use of Various Elements among Respondents Who Reported Strategic Planning Activity}

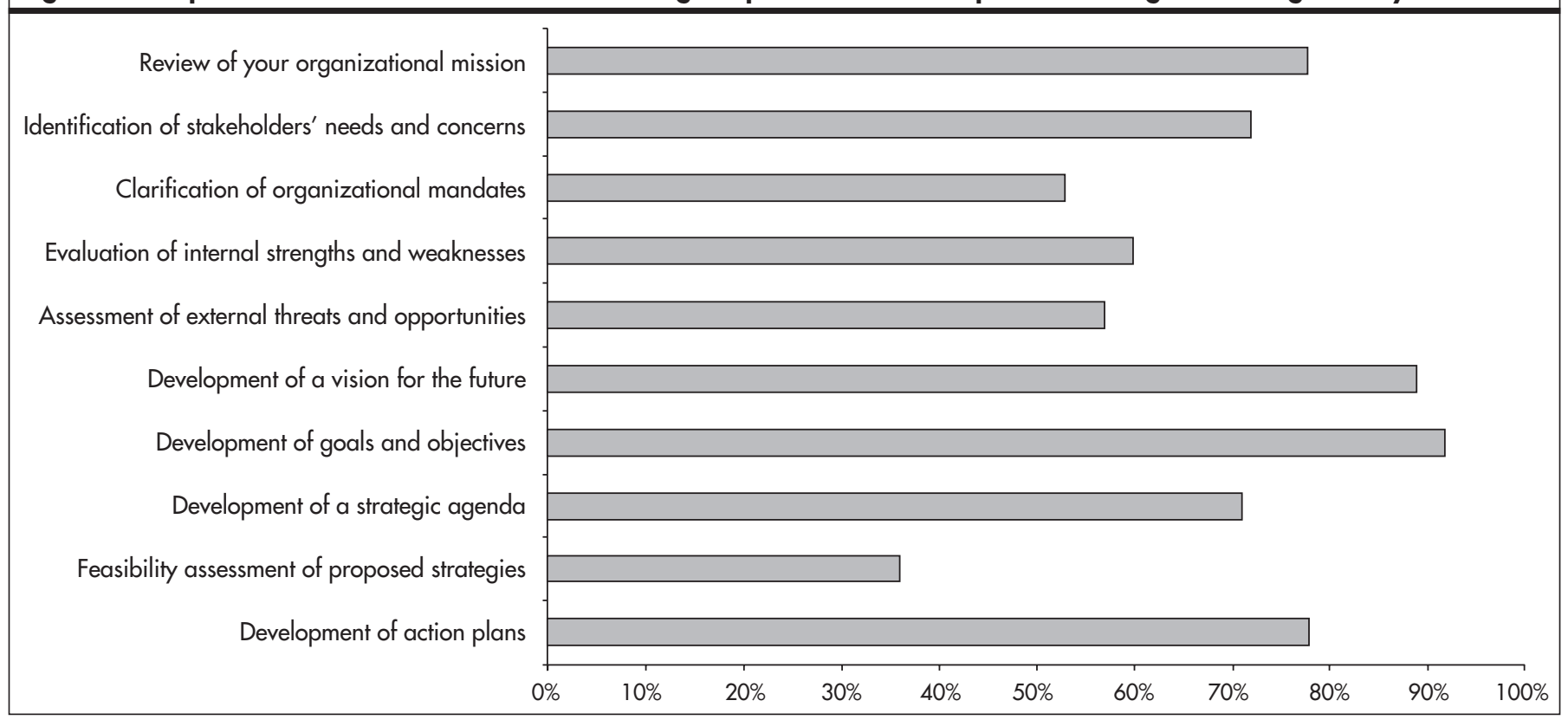


agement capacity in a government jurisdiction was developed by Vinzant and Vinzant (1996a) and consists of four levels:

Level 1: Completion of a full-fledged strategic planning process

Level 2: Production of a strategic planning document

Level 3: Changes in resource allocation to support the accomplishment of strategies

Level 4: Changes in control and evaluation processes to provide feedback on the implementation of strategic plans

Figure 3 represents a simplified attempt to flesh out this model with respect to the municipal governments responding to our survey. First, 56 percent of these cities had not initiated formal, citywide strategic planning in the previous five years, and thus had not begun to develop a strategic management capacity; they might be classified as being at the "pre-strategic management stage." Among jurisdictions that reported involvement in strategic planning, approximately 75 percent indicated they had completed at least one round of the process. Assuming the others will in fact complete the process, then, 44 percent of all of these government units had attained, or will attain, at least level one.

\section{Figure 3 Percent Municipalities Reporting SuccessiveLevels of Strategic Management}

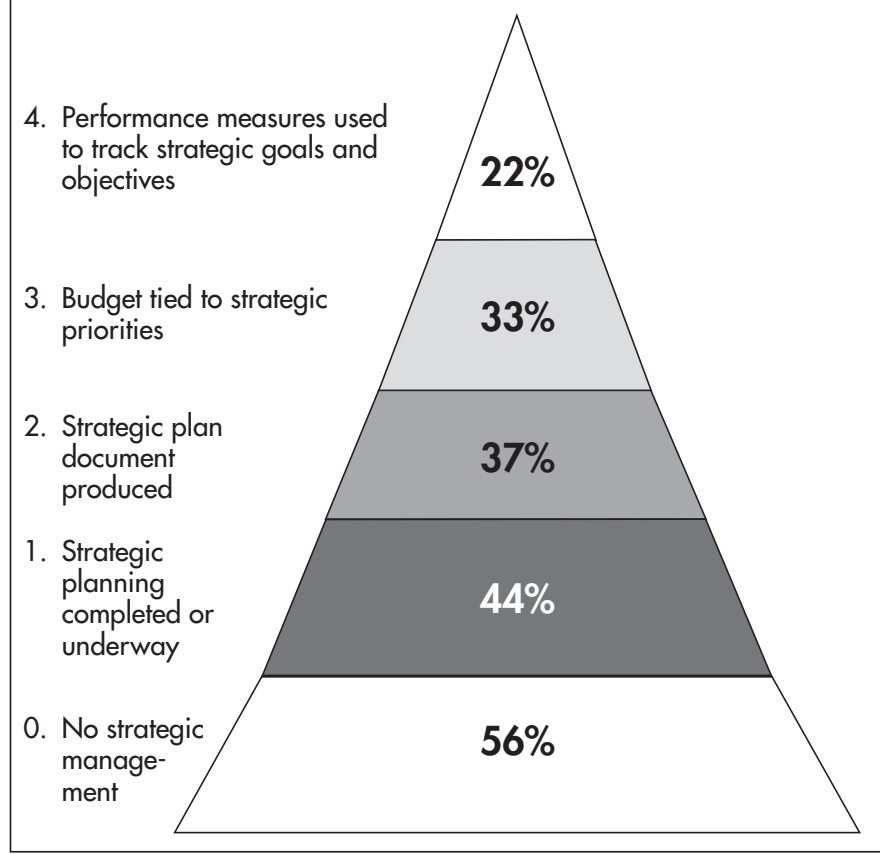

Second, cross-tabular analysis revealed that 83 percent of these cities went on to produce, or were in the process of completing, a strategic plan document. Thus, 37 percent of all the cities in the sample $(0.83 \times 0.44)$ can be classified as having arrived at level two of strategic man- agement capacity. Next, of those cities that reported they had engaged in strategic planning and produced a formal document, nearly 90 percent indicated their annual budgets strongly supported the goals, objectives, and priorities established by their strategic plans. Thus, 33 percent of the sample cities $(0.90 \times 0.37)$ can be classified as having attained level three.

Finally, among cities meeting the strategic planning, documentation, and budgeting criteria, two-thirds reported they use performance measures to track the accomplishment of goals and objectives contained in their strategic plans. Thus, 22 percent of all of the sample cities $(0.67 \mathrm{x}$ 0.33 ) can be classified as having attained level four in the Vinzant and Vinzant model of strategic management capacity. Interestingly, in a study carried out with the Government Accounting Standards Board, Willoughby and Melkers (2001) found that just under 20 percent of the cities and counties that responded to their survey reported using performance measures across the board in conjunction with strategic planning efforts.

\section{Allocating Resources}

Survey respondents from jurisdictions involved in strategic planning were asked a few questions regarding specific connections between their budgets and strategic plans. More than 80 percent indicated the annual budget prepared by their chief administrators strongly supported their strategic goals and objectives, that their capital budgets reflected these goals, and that "new money" in particular was targeted to achieving strategic goals and objectives (table 2). Slightly fewer of these respondents, on the order of 75 percent, reported the strategic plan had a strong influence on the budget requests submitted by department heads and other managers, and that their city councils considered strategic goals and objectives when reviewing annual budgets. However, far fewer of these respondents, only 48 percent, indicated that performance data tied to strate-

\section{Table 2 Cities Linking Budgets to Strategic Plans}

The annual budget prepared by your chief administrator strongly supports the goals, objectives, and priorities established in your strategic plan.

The city council considers strategic goals and objectives when reviewing the annual budget.

The capital budget for your jurisdiction sharply reflects the goals, objectives, and priorities established in your strategic plan.

New money in the budget is targeted to achieving your strategic goals and objectives.

The strategic plan has a strong influence on the budget requests submitted by department heads and other managers.

Performance data tied to strategic goals and objectives play an important role in determining resource allocations. 48 percent Note: Percentages are based on the 225 respondents reporting that their jurisdictions had undertaken formal strategic planning efforts in the past five years. 
gic goals and objectives played an important role in determining the allocation of resources in their cities.

All survey respondents were asked to identify the primary approach to budgeting used by their jurisdiction. Of the 224 respondents who reported their municipal government was involved in strategic planning, slightly more than half indicated they had line-item budgeting systems, while slightly fewer than half indicated they had some form of performance budgeting, program budgeting, zero-based budgeting, or results-based budgeting. Interestingly, those with performance budgeting or program budgeting systems were significantly more likely than those with line-item budgets to report their jurisdictions tied resource allocation to their strategic plans through all six mechanisms listed in table 2. However, those with zero-based or results-based budgeting were more likely than those with line-item budgets to do so through only the last two of those six items.

\section{Table 3 Cities Linking Performance Management Systems to Strategic Plans}

Individual department heads and managers are

responsible for implementing specific initiatives and projects that are part of the strategic plan.

Objectives established for department heads and other managers come from the overall strategic plan.

Annual evaluations of department heads and managers are based largely on their accomplishment of strategic goals and objectives.

Annual salary adjustments in your city are based on contributions to advancing your strategic plan.

The city council holds the chief administrator responsible for implementing the strategic plan.

The evaluation of the chief administrator is based on accomplishment of the strategic goals and objectives.

The chief administrator tries to keep the city council focused on the strategic goals and objectives.

95 percent

83 percent

64 percent

30 percent

77 percent

64 percent

88 percent

Note: Percentages are based on the 225 respondents reporting that their jurisdictions had undertaken formal strategic planning efforts in the past five years.

\section{Performance Management}

Respondents from jurisdictions involved in strategic planning were also asked about the specific links between their strategic plan and performance management system. Fully 95 percent reported that individual department heads and managers were responsible for implementing specific initiatives and projects emanating from their strategic plans, while 83 percent indicated that objectives established for department heads and other managers were derived from the overall strategic plan (table 3). Slightly fewer than twothirds reported that annual evaluations of their senior administrators were based largely on their accomplishment of strategic goals and objectives, while slightly more than three-quarters reported their city councils held chief administrators responsible for implementing strategic plans. However, only 30 percent of these respondents indicated that annual salary adjustments in their jurisdictions were based on individual contributions to advancing the overall strategic plan. In general, then, these jurisdictions target strategic goals and objectives in managers' performance plans, but fewer use these as the basis for evaluating individuals' performance, and far fewer base salary adjustments on the accomplishment of strategic goals and objectives.

Of the respondents indicating their jurisdictions were involved in strategic planning, the great majority reported their cities used some form of management by objectives or formal goal-oriented or performance-oriented process of providing direction and control over the work of managers and employees. Fewer than one out of five reported their jurisdiction did not have such a process. As might be expected, respondents from cities with formal goal-based or performance-based management systems were significantly more likely to report their jurisdictions tied performance management processes to their strategic plan through all seven mechanisms listed in table 3 .

\section{Measurement Processes}

Linking performance measures to strategic plans is far less common than is linking budgets and management processes to strategic plans among cities that have been involved with strategic planning (table 4). Only 56 percent of these respondents reported their jurisdictions used performance measures to track the implementation of projects or other initiatives emanating from their strategic plans, while 60 percent indicated their jurisdictions used measures to track the accomplishment of strategic goals and objectives. Approximately half of these respondents reported their jurisdictions used performance measures to track outcome conditions targeted by their strategic plans,

\section{Table 4 Cities Linking Performance Measures to Strategic Plans}

Your jurisdiction uses performance measures to track the implementation of projects or other initiatives called for by the strategic plan.

Your jurisdiction uses performance measures to track the accomplishment of goals and objectives contained in the strategic plan.

Your jurisdiction uses performance measures to track outcome conditions targeted by your strategic plan.

Your jurisdiction reports performance measures associated with the strategic plan to the city council on a regular basis. 48 percent Your jurisdiction targets programs for more intensive evaluation based on the goals and objectives of your strategic plan.

Your jurisdiction reports performance measures associated with the strategic plan to the public on a regular basis. Your jurisdiction benchmarks performance measures against other jurisdictions to gauge the effectiveness of strategic initiatives.

Your jurisdiction tracks performance data over time to determine whether performance in strategic results areas has improved over previous levels. 56 percent 60 percent 50 percent 54 percent 35 percent Note: Percentages are based on the 225 respondents reporting that their jurisdictions had undertaken formal strategic planning efforts in the past five years. 
that they track performance data over time to determine whether performance in strategic results areas is improving, and that they report measures associated with the strategic plan to their city councils on a regular basis. Finally, only 35 percent of these respondents indicated their jurisdictions reported performance data associated with their strategic plan to the public on a regular basis, or that they benchmark performance measures against other jurisdictions to gauge the effectiveness of strategic initiatives.

Slightly more than half of the respondents from municipalities involved in strategic planning reported their jurisdictions had centralized, citywide performance measurement systems that incorporate most or all departments and programs. Slightly fewer than half, then, indicated their jurisdictions did not have such measurement systems in place. As would probably be expected, consistently and substantially higher percentages of those respondents from jurisdictions with such comprehensive performance measurement systems in place reported links between measures and strategic plans for all eight mechanisms listed in table 4 .

\section{Assessing Results}

Overall, municipal managers in cities engaged in strategic planning tended to rate it quite favorably. Those respondents were asked to what extent they were satisfied with the implementation and achievement of their strategic goals and objectives to date (figure 4). Slightly more than 80 percent of these respondents reported they were satisfied or very satisfied with the results, while fewer than 15 percent indicated they were not sure, and only 5 per- cent said they were dissatisfied with the implementation and achievement of their jurisdictions' strategic goals and objectives.

When asked what percentage of their strategic goals and objectives had actually been accomplished, over two-thirds of the respondents reported that more than 40 percent had been accomplished; nearly one-third indicated that between 60 percent and 80 percent had been accomplished; and more than 10 percent said that 80 percent to 100 percent had been accomplished. Overall, the share of strategic goals and objectives that respondents estimated to have been accomplished by their cities ranged all the way from 0 to 100 percent (figure 5). The average estimated percentage of goals and objectives accomplished was 40 percent among cities having completed one plan, as compared with 60 percent estimated by respondents who reported their jurisdictions had completed multiple rounds of strategic planning. Respondents from jurisdictions with experience in strategic planning were also asked whether the effort had been worth the time and expense, and almost 90 percent affirmed that it was - that the benefits produced by strategic planning outweighed by the costs.

\section{Strategic Planning Impacts}

Toward the end of the survey instrument, respondents from cities involved in strategic planning were presented with a number of dimensions of possible impacts and asked to indicate the extent to which their strategic planning had generated either beneficial or harmful impacts along these lines. Their responses were quite positive (table 5). Negligible numbers of respondents reported any negative impacts, while substantial percentages attributed

Figure 4 Percent Respondents Satisfied with the Implementation and Achievement of Strategic Goals and Objectives

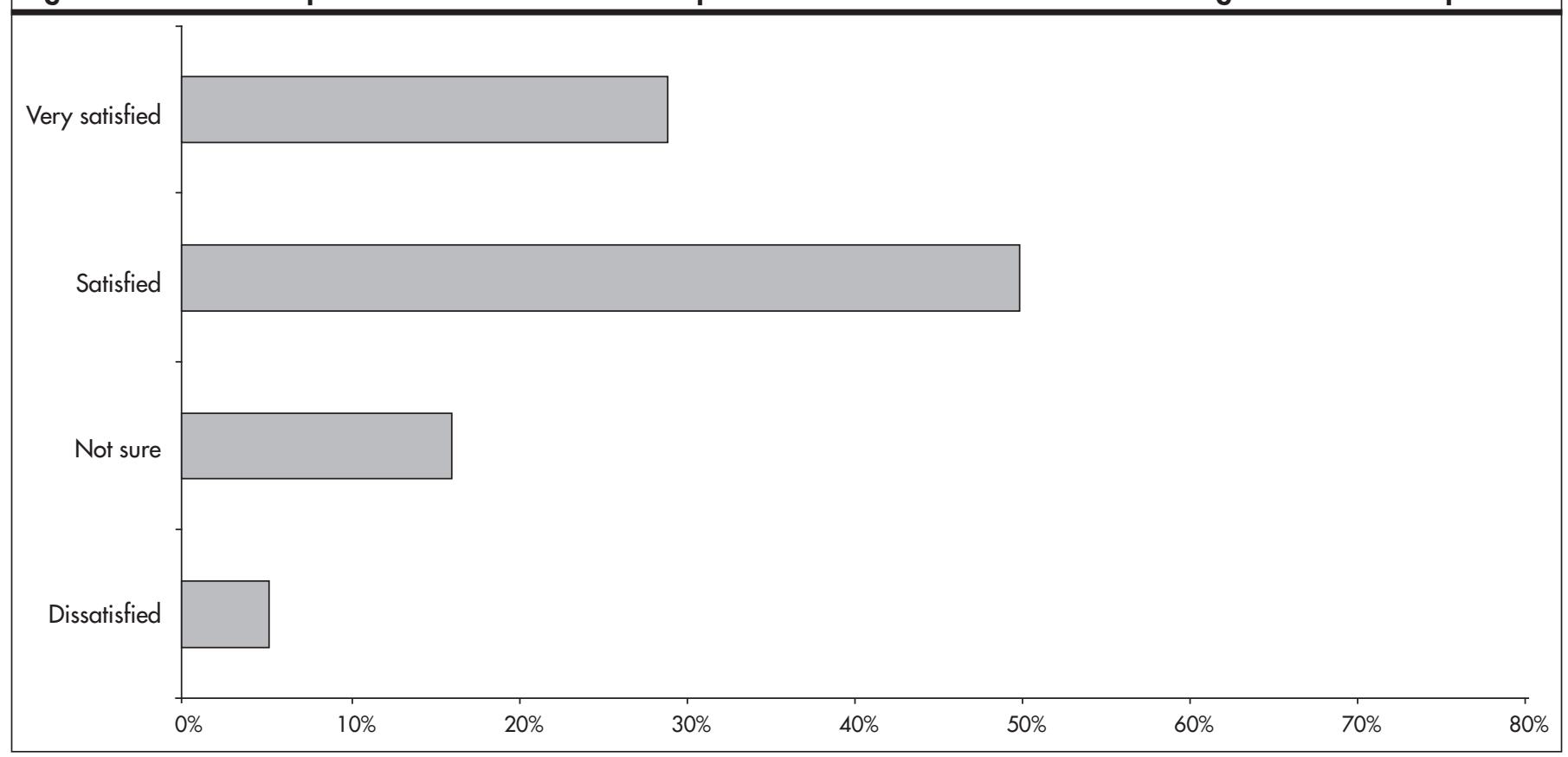




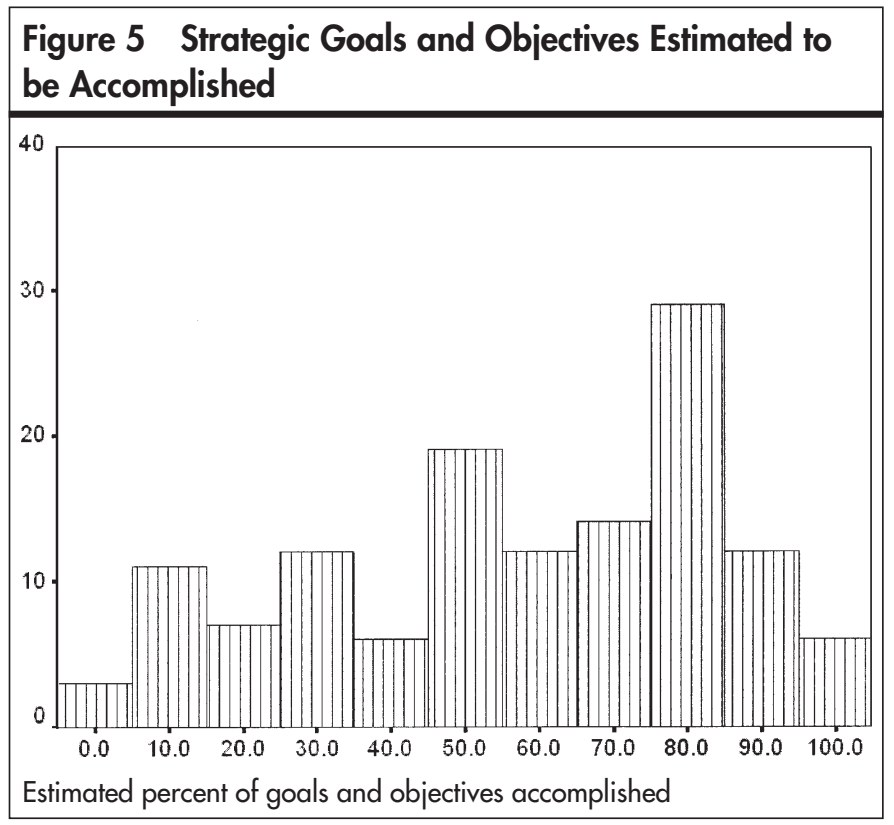

positive impacts to their strategic planning efforts. As might be expected, given the purpose of strategic planning as a tool for focusing direction and priorities, some of the more frequently cited benefits concerned the clarification of mission, goals, and priorities, generally rated as beneficial impacts by 80 percent or more of the respondents (table 5).

These respondents also attributed benefits to their strategic planning efforts in terms of improved external relations, especially with respect to communicating with citizens and external groups (79 percent) and generally maintaining public support (73 percent), and to a lesser

\section{Table 5 Municipalities Rating Various Impacts of Strategic} Planning as Beneficial to Their Jurisdiction

Mission, goals, and priorities

Focusing the city council's agenda on the important issues

Orienting the city to a genuine sense of mission

Enhancing employees' focus on organizational goals

Defining clear program priorities

External relations

Maintaining supportive intergovernmental relations

Communicating with citizen groups and other external stakeholders

Maintaining public support

Management and decision making

Maintaining a functional organizational structure

Implementing effective management systems

Targeting and utilizing program evaluation tools

Making sound decisions regarding programs, systems, and resources

Employee supervision and development

Providing direction and control over employees' activities

Improving employee cohesion and morale

Providing training and development opportunities for employees

Building a positive organization culture in the city

Empowering employees to make decisions and serve the public

Performance

Maintaining your jurisdiction's overall financial condition

Managing operations in an efficient manner

Delivering high-quality public services

Percent

85

85

80

86

Note: Percentages are based on the 225 respondents reporting that their iurisdictions had undertaken formal strategic planning efforts in the past five years. degree, maintaining supportive intergovernmental relations (56 percent). Regarding internal management and decision making, 65 percent reported benefits in maintaining functional organizational structures, 67 percent indicated benefits in implementing effective management systems, and 53 percent saw improvements in targeting and utilizing program evaluation tools, while 83 percent cited improvements in making sound decisions regarding programs, systems, and resources.

With respect to employee supervision and development, 61 percent of respondents reported their strategic planning efforts had yielded benefits in terms of providing direction and control over employee's activities; 48 percent did so in terms of improving employee cohesion and morale; 59 percent indicated improvements in providing training and development opportunities; 75 percent said that strategic planning had helped to build a positive organization culture; and 67 percent reported benefits in terms of empowering employees to make decisions. Finally, and more importantly, many of the respondents reported their strategic planning processes had led to improved performance in terms of maintaining overall financial condition (69 percent), managing operations efficiently (71 percent), and delivering high-quality services ( 89 percent).

\section{Success Factors}

The 19 impact categories listed in table 5 were combined into an unweighted additive index of overall impact. Given five-point Likert scales from "very harmful" to "very beneficial" (coded 1 through 5, respectively), this index could range from a minimum of 19 (all very harmful impacts) to a maximum of 95 (all very beneficial impacts). For the survey respondents from cities involved in strategic planning, the impact index ranged from 32 to 95 , with a mean average of 74 and a standard deviation of 9. Given that a "neutral" average between harmful and beneficial impacts would be 57 (coded with a $3 \times 19$ impact categories), the actual mean of 74 represents substantially favorable ratings.

Thus, most of these respondents reported positive results from their strategic planning efforts. To gauge the most critical factors of success - those that directly contribute to the highest values on the impacts index-we performed several stepwise regression analyses using the additive impact index as the dependent variable. The individual independent variables employed to develop these models included the following:

- The six survey items representing involvement of various stakeholders in the strategic planning process (table 1)

- The 10 items corresponding to various possible elements in the strategic planning process (figure 2) 
- The six items representing mechanisms linking budgets to strategic priorities (table 2)

- The seven items representing linkages between strategies and performance management (table 3)

- The eight items regarding the use of performance measures in connection with strategic plans (table 4).

First, we conducted separate stepwise regression analyses for each block of independent variables to determine the extent to which each component of the strategic management process was associated with the perceived impacts of strategic planning and to identify specific elements most closely correlated with success. The results of these parallel models, based on all of the jurisdictions reporting they had at least initiated strategic planning during the past five years, can be summarized as follows:

Stakeholder Involvement. These variables explained only 17 percent of the variation in the perceived strategic planning impacts, with the following stakeholder groups statistically significant at the 0.05 level:

1. Citizens and other external stakeholders

2. Department heads and other senior managers

3. Lower-level employees.

Planning Elements. The model produced by the stepwise regression process utilizing all 10 planning elements variables, which explained only 9 percent of the variation in the perceived impacts index, included two variables:

1. Feasibility assessment of proposed strategies

2. Development of action plans.

Budgeting Process. The stepwise model based on the six budget-related elements explained 28 percent of the variation in perceived impacts, based on the following variables that were significant at the 0.05 level:

1. The strategic plan has a strong influence on budget requests.

2. Performance data tied to strategic goals and objectives play an important role in determining resource allocations.

3. The capital budget sharply reflects priorities in the strategic plan.

Performance Management. Analysis of the seven performance management elements produced a regression model that explained 32 percent of the variation in the perceived impacts index, with the following significant variables:

1. Annual evaluations of department heads are based on their accomplishment of strategic goals and objectives.

2. Objectives established for department heads and other managers come from the overall strategic plan.

3. Annual salary adjustments are based on contributions to advancing the strategic plan.

Performance Measurement. The stepwise regres- sion model that was developed using the eight elements regarding performance measurement explained 28 percent of the variation in the perceived impacts, incorporating the following variables that were significant at the 0.05 level: 1. Programs targeted for evaluation based on performance related to strategic goals and objectives

2. Performance data tracked over time to assess strategic results

3. Performance measures associated with the strategic plan reported to the public on a regular basis.

Finally, we performed an overall stepwise regression analysis on the impacts index using all of the individual variables in the stakeholders, planning elements, budgeting, performance management, and performance measurement blocks simultaneously, still testing at the 0.05 level. The resulting model incorporates seven variables that explain a total of 45 percent in the overall variation in the impacts index (table 6). The variables included in the model should not necessarily be interpreted as the most fundamental requirements of an effective strategic planning process, but rather should be viewed as leading-edge elements that help to strengthen the overall perceived impact of strategic planning in a municipal jurisdiction.

Interestingly, the first two elements that drive success concern the link between cities' performance management processes and their strategic agendas - namely, establishing objectives for individual department heads and other managers that are derived from the strategic plan and basing annual evaluations on their success in accomplishing strategic goals and objectives. Two of the seven success factors pertain to performance measurement, tracking per-

\section{Table 6 Stepwise Regression Model for Predicting Strategic Planning Impacts}

\begin{tabular}{|c|c|c|c|c|}
\hline \multirow[t]{2}{*}{ Variable } & \multicolumn{3}{|c|}{ Cumulative } & \multirow[b]{2}{*}{ Significance } \\
\hline & Beta & $R^{2}$ & $t S$ & \\
\hline $\begin{array}{l}\text { Objectives established for department } \\
\text { heads and other managers come from } \\
\text { the overall strategic plan }\end{array}$ & .233 & .240 & 3.65 & .000 \\
\hline $\begin{array}{l}\text { Annual evaluations of department heads } \\
\text { and other managers are based on their } \\
\text { accomplishment of strategic goals }\end{array}$ & .200 & .324 & 3.19 & .002 \\
\hline $\begin{array}{l}\text { Jurisdiction reports performance } \\
\text { measures associated with the strategic } \\
\text { plan to the public on a regular basis }\end{array}$ & .118 & .374 & 1.94 & .050 \\
\hline $\begin{array}{l}\text { Feasibility assessment of proposed } \\
\text { strategies (is an important element } \\
\text { of the strategic planning process) }\end{array}$ & .140 & .399 & 2.52 & .013 \\
\hline $\begin{array}{l}\text { Jurisdiction tracks performance data over } \\
\text { time to determine whether performance } \\
\text { in strategic results areas has improved }\end{array}$ & .162 & .419 & 2.59 & .010 \\
\hline $\begin{array}{l}\text { New money in the budget is targeted } \\
\text { to achieving your strategic goals and } \\
\text { objectives }\end{array}$ & .149 & .436 & 2.43 & .016 \\
\hline $\begin{array}{l}\text { Citizens and other external stakeholders } \\
\text { have been centrally involved in the } \\
\text { development of the strategic plan }\end{array}$ & .132 & .451 & 2.35 & .020 \\
\hline Dependent variable: Additive impact index & & $N=2$ & & \\
\hline
\end{tabular}


formance data over time to determine whether performance in strategic results areas are improving, and reporting performance data associated with the strategic plan to the public on a regular basis. Another factor relates to the public, namely, involving citizens and other external stakeholders in the strategic planning process. Regarding elements of the strategic planning process itself, going beyond the generation of options to conducting feasibility assessments of proposed strategies also turned out to be a critical success factor. Finally, the other item that is strongly correlated with beneficial impacts is targeting "new money" in the budget to the achievement of strategic goals and objectives.

\section{Conclusions}

This study was designed to survey the extent to which U.S. municipal governments with populations over 25,000 use strategic planning and management processes, to gauge municipal managers' satisfaction with the results of those processes, and to identify particular strategic planning and management elements that are most closely related to their perceived impacts. The results suggest that the number of cities that have engaged in formal, citywide strategic planning during the past five years is on the order of 40 percent, although such estimates may be inflated to a degree due to the potential of survey noncommit bias that is inherent in the methodology employed here. In addition, the data do not indicate any significant increase in the use of strategic planning by these cities over the past decade. Nevertheless, these results indicate that a substantial number of city governments in the United States-though well under a majority - are using or at least have used strategic planning to establish long-term direction, determine priorities, and guide decision making.

Among cities that engage in strategic planning, high percentages also report the use of particular budgeting, performance management, and measurement practices aimed at implementing strategic plans effectively. Somewhat surprisingly, linking performance measures to strategic plans appears to be far less common than linking budgets or performance management systems to strategic plans. Thus, only about one in five of the cities that reported strategic planning activity also claim to employ a mix of approaches that would suggest the beginning of a comprehensive strategic management process.

However, municipal managers from cities that have engaged in strategic planning appear to be enthusiastic about it. A large majority of these managers reported they are satisfied with the implementation of strategic initiatives and the achievement of strategic goals and objectives, and almost 90 percent of them affirmed the benefits generated by strategic planning outweighed the costs of undertaking these efforts. Furthermore, these municipal managers tend to see numerous beneficial impacts of their strategic planning efforts, with very few of them citing harmful impacts. Finally, the success factors identified by this research as driving positive results_elements that separate jurisdictions with even more beneficial perceived impacts at the margin-involve linking individual performance with strategic goals and objectives, reporting strategic performance measures to the public, evaluating the feasibility of proposed strategies, tracking performance data over time, targeting new money in the budget to achieve strategic goals, and involving external stakeholders in the planning process in the first place.

This research explores the state of the practice of strategic management in local government using a framework drawn from the extensive literature on strategic planning and decision making in the public sector.

Not surprisingly, despite high aspirations among managing-for-results proponents about the deployment of results-oriented management tools, this research found cities all over the "performance curve" in their use of strategic planning and related strategic management approaches. Although results-oriented management has been the centerpiece of the public management reform movement over the past 15 years or so, formal strategic planning has yet to become regular and standard practice in municipal jurisdictions in the United States. However, our study does show continuing growth and development in the field-a raising of the bar-with leading-edge jurisdictions that are broadening their strategic planning efforts into more sophisticated and comprehensive, and reportedly more effective, strategic management approaches. 


\section{References}

Aristigueta, Maria Pilar. 1999. Managing for Results in State Government. Westport, CT: Quorum Books.

Backoff, Robert, Barton Wechsler, and R.E.J. Crew. 1993. The Challenge of Strategic Management in Local Government. Public Administration Quarterly 17(2): 127-45.

Berry, Frances Stokes, and Barton Wechsler. 1995. State Agencies' Experience with Strategic Planning: Findings from a National Survey. Public Administration Review 55(2): 15968.

Broom, Cheryle A. 1995. Performance-Based Government Models: Building a Track Record. Public Budgeting and Finance 15(4): 3-17.

Bryson, John M. 1995. Strategic Planning for Public and Nonprofit Organizations: A Guide to Strengthening and Sustaining Organizational Achievement. Rev. ed. San Francisco: Jossey-Bass.

Denhardt, Robert B. 1985. Strategic Planning in State and Local Government. State and Local Government Review 17(4): 17479.

Dodge, William R., and Douglas C. Eadie. 1982. Strategic Planning: An Approach to Launching New Initiatives in an Era of Retrenchment. Management Information Service Report 14(9): 1-13.

Donald, Carrie G., Thomas S. Lyons, and Rebecca C. Tribbey. 2001. A Partnership for Strategic Planning and Management in a Public Organization. Public Performance and Management Review 25(2): 176-93.

Eadie, Douglas C. 1983. Putting a Powerful Tool to Practical Use: The Application of Strategic Planning in the Public Sector. Public Administration Review 43(5): 447-53.

2000. Change in Chewable Bites: Managing the Strategic Change Portfolio. In Handbook of Strategic Management, 2nd ed., edited by Jack Rabin, 123-39. New York: Marcel Dekker.

Ellingson, Dee Ann, and Jacob R. Wambsganss. 2001. Modifying the Approach to Planning and Evaluation in Governmental Entities: A "Balanced Scorecard" Approach. Journal of Public Budgeting, Accounting and Financial Management 13(1): 103-20.

Franklin, Aimee L. 2000. An Examination of Bureaucratic Reactions to Institutional Controls. Public Performance and Management Review 24(1): 8-21.

- 2001. Serving the Public Interest? Federal Experiences with Participation in Strategic Planning. American Review of Public Administration 31(2): 126-38.

Gabris, Gerald T. 1989. Educating Elected Officials in Strategic Goal Setting. Public Productivity and Management Review 13(2): 161-76.

Gargan, John J. 1989. Strategic Management in City Government: Continuing the Interplay of Rationality and Politics. In Handbook of Strategic Management, edited by Jack Rabin, Gerald J. Miller, and W. Bartley Hildreth, 403-23. New York: Marcel Dekker.
Geletkanycz, Marta A., and Donald C. Hambrick. 1997. The External Ties of Top Executives: Implications for Strategic Choice and Performance. Administrative Science Quarterly 42(4): 654-82.

Halachmi, Arie, William Patrick Hardy, and Bernie Lee Rhoades. 1993. Demographic Data and Strategic Analysis. Public Administration Quarterly 17(2): 159-74.

Hatry, Harry P. 2002. Performance Measurement: Fashions and Fallacies. Public Performance and Management Review 25(4): 352-58.

Hendrick, Rebecca. 2000. Comprehensive Management and Budgeting Reform in Local Government. Public Productivity and Management Review 23(3): 312-37.

Kaplan, R.S., and D.P. Norton. 1996. The Balanced Scorecard: Translating Strategy into Action. Boston: Harvard Business School Press.

Koteen, Jack. 1989. Strategic Management in Public and Nonprofit Organizations: Thinking and Acting Strategically on Public Concerns. New York: Praeger.

Markoczy, Livia. 2001. Consensus Formation during Strategic Change. Strategic Management Journal 22(11): 1013-31.

Melkers, Julia, and Katherine Willoughby. 1998. The State of the States: Performance-Based Budgeting Requirements in 47 out of 50 States. Public Administration Review 58(1): 6673.

Mintzberg, Henry. 1994. The Rise and Fall of Strategic Planning: Reconceiving Roles for Planning, Plans, Planners. New York: Free Press

Newcomer, Kathryn, Edward T. Jennings, Cheryle Broom, and Allen Lomax. 2002. Meeting the Challenges of PerformanceOriented Government. Washington, DC: American Society for Public Administration, Center for Accountability and Performance.

Nutt, Paul C., and Robert W. Backoff. 1992. Strategic Management of Public and Third Sector Organizations: A Handbook for Leaders. San Francisco: Jossey-Bass.

Osborne, David, and Ted Gaebler. 1992. Reinventing Government: How the Entrepreneurial Spirit Is Transforming the Public Sector. Reading, MA: Addison-Wesley.

Poister, Theodore H., and Gregory Streib. 1994. Municipal Management Tools from 1976 to 1993: An Overview and Update. Public Productivity and Management Review 18(2): 115-25.

- 1999. Strategic Management in the Public Sector: Concepts, Models, and Processes. Public Productivity and Management Review 22(3): 308-25.

Poister, Theodore H., and David M. Van Slyke. 2002. Strategic Management Innovations in State Transportation Departments. Public Performance and Management Review 26(1): 8-74.

Roberts, Nancy. 2000. The Synoptic Model of Strategic Planning and the GPRA: Lacking a Good Fit with the Political Context. Public Productivity and Management Review 23(3): 297-311. 
Sorkin, Donna L., Nancy B. Ferris, and James Hudak. 1984. Strategies for Cities and Counties: A Strategic Planning Guide. Washington, DC: Public Technology.

Steiss, Alan Walter. 1985. Strategic Management and Organizational Decision-Making. Lexington, MA: D.C. Heath.

Streib, Gregory. 1992. Applying Strategic Decision Making in Local Government. Public Productivity and Management Review 15(3): 341-55.

Streib, Gregory, B.J. Slotkin, and Mark Rivera. 2001. Public Administration Research from a Practitioner Perspective. Public Administration Review 61(5): 515-25.

Swanstrom, Todd. 1987. The Limits of Strategic Planning for Cities. Journal of Urban Affairs 9(2): 139-57.

Toft, Graham S. 1989. Synoptic (One Best Way) Approaches of Strategic Management. In Handbook of Strategic Management, edited by Jack Rabin, Gerald J. Miller, and Hildreth W. Hildreth, 3-34. New York: Marcel Dekker.

Vinzant, Douglas H., and Janet Vinzant. 1996a. Strategy and Organizational Capacity: Finding a Fit. Public Productivity and Management Review 20(2): 139-57.

1996b. Strategic Management and Total Quality Management: Challenges and Choices. Public Administration Quarterly 20(2): 201-19.

Willoughby, Katherine G., and Julia E. Melkers. 2001. Performance Budgeting in the States. In Quicker, Better, Cheaper? Managing Performance in American Government, edited by Dall Forsythe, 335-64. Albany, NY: Rockefeller Institute Press.

Zanetti, Lisa A., and Robert B. Cunningham. 2000. Perspectives on Public Sector Strategic Management. In Handbook of Strategic Management, 2nd ed., edited by Jack Rabin, 554-60. New York: Marcel Dekker. 